monitor data. Behavior Research Methods \& Instrumentation, $1981,13,107-111$.

Kliegl, R., Olson, R. K., \& Davidson, B. J. On problems of unconfounding perceptual and language processes. In $K$. Rayner (Ed.), Eye movements in reading: Perceptual and language processes. New York: Academic Press, in press.

Kučera, H., \& Francis, W. N. Computational analysis in presentday American English. Providence, R.I: Brown University Press, 1967.

McClelland, J. L., \& Rumelhart, D. E. An interactive activation model of context effects in letter perception. Part 1 . An account of basic findings. Psychological Review, 1981, 88, 375407.

McConkıe, G. W. Evaluating and reporting data quality in eye movement research. Behavior Research Methods \& Instrumentation, 1981, 13, 97-106.

McConkie, G. W., Hogaboam, T. W., Wolverton, G. S., Zola, D., \& Lucas, P. A. Toward the use of eye movements in the study of language processing. Discourse Processes, 1979, 2, 157-177.

McConkie, G. W., \& Rayner, K. The span of the effective stimulus during a fixation in reading. Perception \& Psychophysics, 1975, 17, 578-586.

Mitchell, D. C., \& Green, D. W. The effects of context and content on immediate processing in reading. Quarterly Journal of Experimental Psychology, 1978, 30, 609-636.

O'REgAN, J. K. Saccade size control in reading: Evidence for the linguistic control hypothesis. Perception \& Psychophysics, 1979, 17, 578-586.

O'REGAN, J. K. The control of saccade size and fixation duration in reading: The limits of linguistic control. Perception \& Psychophysics, 1980, 28, 112-117.
O'REGAN, J. K. The "convenient viewing position" hypothesis. In D. F. Fisher, R. A. Monty, \& J. W. Senders (Eds.), Eye movements: Cognition and visual perception. Hillsdale, N.J: Erlbaum, 1981.

Perfetti, C. A., Goldman, S. R., \& Hogaboam, T. W. Reading skill and the identification of words in discourse context. Memory \& Cognition, 1979, 7, 273-282.

PynTE, J. Readiness for pronunciation during the reading process. Perception \& Psychophysics, 1974, 16, 487-504.

RAYNER, $K$. The perceptual span and peripheral cues in reading. Cognitive Psychology, 1975, 7, 65-81.

RAYNER, $K$. Eye guidance in reading: Fixation locations within words. Perception, 1979, 8, 21-30.

Rayner, K., McConkie, G. W., \& Ehruich, S. Eye movements and integrating information across fixations. Journal of Experimental Psychology: Human Perception and Performance, 1978, 4, 529-544.

Terry, P., Samuels, S. J., \& LaBerge, D. The effect of letter degradation and letter spacing on word recognition. Journal of Verbal Learning and Verbal Behavior, 1976, 15, 577-585.

NOTE

1. The presence of suppressor variables in the model can lead to increments in the variance accounted for that are not due to the variable added in the last step but are the result of the simultaneous presence of two varlables. Fortunately, there are procedures to determine whether or not suppressor effects are present (Cohen \& Cohen, 1975; Conger, 1974).

(Received for publication October 6, 1981; revision accepted February 10, 1982.)

\title{
ANNOUNCEMENT \\ Twenty-Third Annual Meeting of the Psychonomic Society
}

The 23rd annual meeting of of the Psychonomic Society will be held at the Hyatt Regency Hotel in Minneapolis, Minnesota, November 11-13, 1982. The Call for Papers will be mailed to Society members during May 1982. Papers dealing with the application of psychological science to real-world problems are encouraged. The program and hotel reservation forms will be mailed to members in the early fall. The program will also be printed in the September issue of the Bulletin of the Psychonomic Society. The SecretaryTreasurer, J. Bruce Overmier, may be contacted for further information at the Department of Psychology, University of Minnesota, Minneapolis, Minnesota 55455 [(612) 373-3430]. 